\title{
Relations between young adults' knowledge and understanding, experiences, and information behavior in personal finance matters
}

\author{
Manuel Förster ${ }^{1 *} \mathbb{D}$, Roland Happ ${ }^{2}$ and W. B. Walstad ${ }^{3}$
}

\section{${ }^{*}$ Correspondence:}

manuel.

foerster@uni-bamberg.de

${ }^{1}$ Faculty of Social Sciences,

Economics, and Business Administration, Chair

for Business and Economics Education, Otto Friedrich

University of Bamberg,

Kärntenstraße 7 .

96052 Bamberg, Germany

Full list of author information

is available at the end of the article

\begin{abstract}
Background: In Germany, general secondary education offers few opportunities for young adults to acquire knowledge and understanding of personal finance. Hence, apart from parents' influence as role models, important influences on young adults' financial knowledge and understanding likely include their personal experience with financial products and their behavior of informally seeking information about specific financial products.
\end{abstract}

Methods: In this paper, we investigate the relationships between these latter variables based on a sample of 1108 young adults from Germany, aged 17-25, beginning their studies in higher education. Knowledge and understanding of personal finance was assessed using the German adaptation of the US Test of Financial Literacy. In this paper, we focus on the dimension 'Banking' (covering financial investing, saving, using credit). In addition, we surveyed young adults' experience in basic personal finance matters (e.g., having a bank account, using a credit card, paying for rent) and their information behavior towards specific financial products (e.g., stocks, investment, retirement plans, and insurance).

Results: The data set was prepared through multiple imputation and analyzed using regression models. The results show clear correlations between knowledge and understanding in the dimension 'Banking' and both experience and information behavior in personal finance matters.

Conclusions: Our findings illustrate how important it is that young adults obtain experience with and actively inform themselves about financial products, particularly in countries such as Germany where personal finance is not taught extensively and systematically in school.

Keywords: Knowledge and understanding of personal finance, Financial literacy, Financial experience, Information behavior, Bank account, Credit card, Stocks 


\section{Relevance}

Schools in Germany offer few opportunities for students to acquire knowledge and develop an understanding in personal finance matters. Curricular analyses indicate that the school curricula, especially in general secondary education, make hardly any reference to personal financial content (see Förster et al. 2017; Retzmann and Seeber 2016). ${ }^{1}$ Correspondingly, some research studies report insufficient levels of knowledge and understanding in personal finance matters (see Bender 2012; Bertelsmann Foundation 2004; Erner et al. 2016; Schuhen and Schürkmann 2014). Surveys conducted by, e.g., the Federal Association of German Banks (BdB) and the Association for Consumer Research show that $75 \%$ of young adults would prefer to learn more about finance-related topics in school (BdB 2015, p. 30). Barry (2016) finds that the majority of young adults in Germany feel highly insecure when dealing with insurances, and saving and planning income. This finding needs to be viewed all the more critically given that, over the last two decades, the German government has ceded parts of the insurance sector to private insurers. Hence, demands on citizens to understand and evaluate insurances have increased. Demands on young adults' financial literacy are very high also in the area of banking, as illustrated, e.g., by the multitude of available financial products for saving, using credit, and financial investing.

The lack of personal finance instruction in the school curricula in Germany means that other factors such as family background and practical experiences with financial products are likely to play a greater role in shaping knowledge and understanding of personal finance among young adults. Studies investigating the relation between family background and knowledge and understanding of personal finance indicate that not all families assume equally the responsibility for financial education (see e.g., Lusardi et al. 2010; OECD 2014, pp 84-90). According to these studies, e.g., the extent to which knowledge and understanding of personal finance are fostered in the family is influenced by the family's socio-economic status (see Lusardi et al. 2010; OECD 2017, pp 97-98) as well as migration background (e.g., Brown and Graf 2013; Cameron et al. 2014; Worthington 2006).

Given this uncertainty and the fact that knowledge and understanding of personal finance and corresponding content are not sufficiently represented in the school curricula in Germany, we focused on further key factors, including young adults' personal experiences with and information behavior towards financial products. This study, therefore, investigates young adults' knowledge and understanding of personal finance and its relation to personal experiences with and information behavior towards various financial products from the area of banking.

We start by describing the construct of knowledge and understanding of personal finance in "Theoretical background and state of research" section and place it within the wider context of financial literacy. "Theoretical background and state of research" section also includes a literature review on the relations between young adults' knowledge

\footnotetext{
${ }^{1}$ An exception are specialized commercial vocational education schools. Depending on the vocational training course, personal finance content to a smaller or larger extent forms part of the curriculum, for instance in the training of banking professionals (see Happ and Förster 2017). Hence, it is not surprising that young adults who have completed a commercial vocational training show a higher knowledge level in personal finance. This also applies to the results in this paper. The empirical models underline the benefit of completing a commercial vocational training to acquire knowledge and understanding of personal finance.
} 
and understanding, financial experiences and information behavior regarding specific financial products. On this basis, we derive the hypotheses for the study. In "Measurement instrument and sample" section, we present the measurement instrument used to assess knowledge and understanding of personal finance: the Test of Financial Literacy. We further narrow down our analyses in this paper to the dimension 'Banking' in the test, beginning by reporting descriptive statistics about the sample of young adults $(\mathrm{N}=1108)$ and the variables assessed. "Empirical modeling and results" section shows the results of the empirical analysis for testing the postulated relationships. In "Discussion" section, we close with a critical discussion of the findings and in "Conclusions and limitations" section we point out implications and limitations of the study and potential for further research.

\section{Theoretical background and state of research}

\section{Concept of knowledge and understanding of personal finance}

In the research literature, various terms are used to refer to knowledge and understanding of personal finance, including financial capability, financial knowledge, financial competency, financial well-being and, particularly in English-speaking countries, financial literacy (see Erner et al. 2016; Huston 2010; Johnson and Sherraden 2007; Remund 2010; Schuhen and Schürkmann 2014). The range of terminology illustrates that there is no clear consensus on how to define financial literacy (Frühauf and Retzmann 2016). Aprea and Wuttke (2016, p. 402), describe financial literacy as the "potential that enables a person to effectively plan, execute, and control financial decisions." According to Atkinson and Messy (2012), financial literacy draws from three separate but related dimensions: knowledge, behavior, and attitudes. Lusardi and Mitchell (2011, p. 6) state that financial literacy means "peoples' ability to process economic information and make informed decisions about financial planning, wealth accumulation, debt, and pensions". Many studies they cite in their extensive review of the literature measure financial literacy based on knowledge and understanding of a set of financial concepts (see Hastings et al. 2013).

For this study, we focus on the cognitive dimension of financial literacy, which includes knowledge and understanding of personal finance, as a prerequisite for financially sound decisions (Förster et al. 2017). The financial knowledge component is a common denominator in most definitions of financial literacy for students (see CEE 2013; OECD 2017). The literature also discusses which content areas should form part of financial knowledge (see Huston 2010; Remund 2010; Schuhen and Schürkmann 2016). In the United States, the Council for Economic Education (CEE) has issued the National Standards for Financial Literacy, which specify six content areas of financial literacy: earning income, buying goods and services, saving, using credit, financial investing, and protecting and insuring (CEE 2013). These standards also appear to be valid for use with young adults in Germany based on expert interviews to ensure that these content areas were relevant (for the preliminary study and results, see Happ et al. 2018). In our paper, we focus on the dimension 'Banking' from the Test of Financial Literacy, which covers the content areas financial investing, saving and using credit. Further, this study focuses on young adults' experience with and information behavior towards various financial products that are common in Germany. In "State of research and hypotheses" section, we review 
research on these variables and discuss the possible relationship between knowledge and understanding of personal finance and the experiences and information behavior of young adults with personal finance matters.

\section{State of research and hypotheses}

A general observation helps to characterize the state of research on financial literacy in Germany and offers an international perspective on the reviewed studies. Germany does participate in PISA, however not in the financial literacy section (see OECD 2017, p. 71; Schuhen and Schürkmann 2016, p. 383). This omission indicates that knowledge and understanding of personal finance is not currently considered to be an important topic for national study and as a consequence there are few studies of it. ${ }^{2}$ Nevertheless over the last decade, the number of research studies on this topic has increased in Germany, including most notably Aprea and Wuttke (2016), Barry (2016), Bender (2012), Erner et al. (2016), Liedtke (2015), Schuhen and Schürkmann (2014).

\section{a. Experience with financial products}

Regarding the relationship between knowledge and understanding of personal finance and experiences with financial products, we considered particularly experiences with two financial products: bank accounts and credit cards. A finding from the most recent PISA (OECD 2017, p. 16) is that more experience with basic financial products is correlated to greater knowledge and understanding in personal finance matters. Bank accounts are the most widely used financial products among young adults in Germany (see Norden and Weber 2007, p. 4). For the purposes of this study, we must note that, according to a study by GfK Market Research Consumer Panel Projects (Gesellschaft für Konsumforschung, GfK 2015), only a small share of 18- to 25-year-olds can be expected to not own a bank account. In Germany, the vast majority of the total population of young adults in this age group (around 91 percent) can indeed be expected to own a bank account (see "Empirical modeling and results" section). ${ }^{3}$ Furthermore, PISA found a relationship with financial literacy for 10 out of 13 participating countries that gathered data on ownership of basic financial products. The relationship was significant even after controlling for parents' socioeconomic background (OECD 2017, p. 111). These recent findings from PISA are similar to findings from earlier studies by Peng et al. (2007), who found that young adults' experience with financial products (e.g. ownership of a bank account) explained a greater share of variance in financial knowledge than students' attendance of a high school course on personal finance. This type of relationship between financial knowledge and ownership of a bank account has also been reported in studies by Zhan et al. (2006, p. 64) and Sohn et al. (2012, p. 8). ${ }^{4}$ Accordingly, our first hypothesis is the following:

\footnotetext{
${ }^{2}$ While we do not present international comparative analyses between Germany and the United States in this paper, the adapted test instrument allows for them to be carried out in future research.

3 This explains the small amount of young adults in our sample who do not own a bank account (see the description of the sample in "Measurement instrument and sample" section).

${ }^{4}$ For Germany, such analyses have not been done by assessing the knowledge and understanding of personal finance by means of a test instrument.
} 
H1a Young adults in Germany who own a bank account show greater knowledge and understanding of personal finance than young adults who do not own a bank account.

On the relationship between knowledge and understanding of personal finance and ownership of a credit card, the literature suggests that the relationship is a weak one. ${ }^{5}$ Walstad et al. (2010, p. 352) found no relationship between financial knowledge scores and use of a credit card for US high school students. Similar results were found in most countries participating in the PISA study section on financial literacy (OECD 2014, p. 102). Furthermore, no relationship was found in PISA between holding a prepaid debit card and performance on a financial literacy test. None of these studies, however, were conducted with young adults in Germany, and cross-national differences can be expected, especially with regard to credit cards. While it is everyday practice for young adults in the US to use credit cards as a common means of payment, in Germany, credit cards are used much less often (see German Central Bank 2015, p. 20; Norden and Weber 2007, p. 4). Many German banks will issue credit cards only to customers who have regular incoming payments to their accounts. For everyday payment transactions, debit cards are available in Germany, as well, and are widely accepted in retail. Overall, young adults in Germany own or use a credit card less often than young adults in the US (Bagnall et al. 2014). Accordingly, given the research evidence insignificant or weak effects of credit card ownership on financial literacy and the limited use of credit cards by young adults in Germany we formulated the following hypothesis.

H1b Young adults in Germany who own a credit card show no greater knowledge and understanding of personal finance than young adults without a credit card.

\section{b. Disposable income}

The amount of money that young adults have at their disposal is related to their parents' socioeconomic background. Chen and Volpe (1998) as well as Breitbach and Walstad (2016, p. 90) found a positive correlation between disposable income and knowledge and understanding of personal finance. These findings were also supported by Grohmann and Menkhoff (2015, p. 658), who confirmed that a higher disposable income is positively correlated with financial education and financial behavior. Moreover, numerous studies have already shown that knowledge and understanding of personal finance is significantly influenced by parents' socioeconomic background (see, e.g., Atkinson and Messy 2012; Lusardi et al. 2010; OECD 2017). On this basis, we formulated the following hypothesis, assuming that not only parents' socioeconomic background, but particularly young adults' disposable income should be correlated:

H2 Young adults with a higher amount of disposable income show greater knowledge and understanding of personal finance than young adults with a lower amount of disposable income.

\footnotetext{
${ }^{5}$ In this paper, we examine the relation between ownership of a credit card and knowledge and understanding of personal finance. It is worth noting that there is a larger number of studies on the reverse relation, analyzing the influences of high levels of personal finance knowledge on the use of credit cards (see, e.g., Allgood and Walstad 2016; Lusardi and Tufano 2015).
} 
In this study, we focused on young adults who were beginning their studies in higher education (see sample description in "Measurement instrument and sample" section). Within this group, it was unlikely that all participants would earn a regular income. Many of them would likely depend on financial support from their parents or government grants ${ }^{6}$ to pay the rent for their apartment. Hence, in the empirical analysis, we were interested whether such differences in the personal financing structure in the sample, e.g., with regard to financing of rent show the relationship to knowledge and understanding of personal finance (see "Empirical modeling and results" section).

\section{c. Information behavior towards specific financial products}

Even if young adults at this stage of life may not use many financial products through such activities as the buying and selling of stock, managing a portfolio of investments, or planning for retirement (e.g., participating in a Riester retirement plan ${ }^{7}$ ), they may still already have gathered information about them from different sources. They may have read about the topics of stocks, investments, and retirement planning, discussed them with their parents or other adults, or learned something about them through the news media. Atkinson et al. (2006, p. 24) reported a significant correlation of 72 between financial knowledge and "staying informed" about certain financial products. They also found that doing well at "staying informed" was strongly correlated with better outcomes in the approaches taken to "choosing products" in finance. Lusardi et al. (2010) found for young adults (ages 23-28) greater family financial sophistication, as measured by family ownership of stocks or having retirement savings, was associated with higher levels of financial literacy. Van Rooij et al. (2007) assessed not only young adults, but older participants and report a positive correlation between consumption of informal sources of information on financial products and high levels of financial literacy. This positive correlation between individual need for information on financial products and level of financial literacy was also confirmed by Sprenger (2016). Based on these findings, we formulated hypothesis 3 as follows:

H3 Young adults who inform themselves more about financial products show greater knowledge and understanding of personal finance than young adults who inform themselves less about financial products.

\section{Measurement instrument and sample}

To operationalize knowledge and understanding of personal finance, we used the internationally established Test of Financial Literacy (TFL; Walstad and Rebeck 2017) by the US CEE. The TFL is based on the National Standards for Financial Literacy (CEE 2013)

\footnotetext{
${ }^{6}$ In Germany, students can finance their studies not only through bank loans, but also through government grants (combining a grant and an interest-free loan) according to the German Federal Training Assistance Act (BaföG); eligibility depends on socioeconomic factors, particularly on the parents' financial situation.

7 A common grant-aided privately funded pension scheme.
} 
and comprises 45 items in multiple-choice format. ${ }^{8}$ Each item includes a stem with a brief situation outline and four response options, including one correct answer (Walstad and Rebeck 2017). The 45 TFL items operationalize the six content areas laid out in the National Standards for Financial Literacy (see "Concept of knowledge and understanding of personal finance" section): earning income, buying goods and services, saving, using credit, financial investing, and protecting and insuring (for further information on the content areas, see CEE 2013). The TFL was adapted for use in Germany following an extensive process that used international translation standards (see Förster et al. 2017).

At the start of the winter term 2015/2016 and the summer term 2016, a paper-pencil test was administered to beginning students from various degree courses in higher education. Altogether 1108 young adults were assessed. The sample was restricted to 17- to 25-year-olds, because we assumed that older participants would have had disproportionately more opportunities to learn about personal finance from everyday practical experiences in financial situations. Particularly for students at the beginning of their studies, knowledge of personal finance is highly important. Most beginning students have to manage a household on their own for the first time in their lives, which includes managing a personal financial budget. Often, they also enter into certain contracts on their own for the first time, such as rental contracts or cell phone contracts, which require financial decisions.

A factor analysis of the TFL showed that the test items by financial literacy standard can be grouped into three dimensions: 'everyday money management' (earning income, buying goods and services), 'Banking' (financial investing, saving, using credit), and 'insurance' (protecting and insuring) (see Förster et al. 2018). In the following analyses, we focus only on the dimension of 'Banking. We assumed that this category in particular would show correlations with experience with financial products and active information behavior towards financial products. The dimension includes 22 of the 45 items and covers knowledge and understanding of financial products such as stocks, mutual funds, bonds, credit, private pension plans, entries in credit history, account keeping, business law, and so on. We need to stress that, since we limited analyses to the content dimension 'Banking', results can be interpreted confidently only for this content area, and only tentatively with regard to the entire construct of knowledge and understanding of personal finance (see also section limitations). To keep testing time short, our survey also focused only on information behavior towards financial products for banking.

Below are two example items (item 30 and item 32) from the dimension 'Banking' (see Fig. 1), which both focus on the topic of stocks/equity funds. The items are shown in the original US version (TFL) and in the adapted German version (TFL-G), with documentation of adaptations and modifications to facilitate interpretation.

In addition, a questionnaire was administered to gather data on test-takers' experiences with and information behavior towards financial products. Questions included,

\footnotetext{
${ }^{8}$ Originally, the TFL included 50 items (see Walstad and Rebeck 2016). After initial testing in the US, the instrument was shortened to its current version of 45 items, mainly to facilitate practical use. Cutting down testing time to approximately $45 \mathrm{~min}$ has made it possible to administer the test within one school lesson.
} 
30. Stock $A$ has been issued by a new corporation Stock B is considered a "blue chip" stock. Which is true about these two stocks?

A. Stock $A$ is expected to be relatively more risky than stock $B$.*

B. Stock B is expected to earn a higher rate of return than stock $A$.

C. Stock B is expected to pay a guaranteed rate of return and stock $A$ will not.

D. Stock $A$ is expected to hold its value better than Stock B if interest rates rise.
30. Aktie A wurde von einem neuen Unternehmen ausgegeben. Aktie B stammt von einem großen DAX-Unternehmen. Welche Aussage zu den zwei Aktien ist richtig?

A. Aktie A gilt als vergleichsweise riskanter als Aktie B.*

B. Aktie B wird voraussichtlich eine höhere Rendite erbringen als Aktie A.

C. Bei Aktie B wird erwartet, dass sie eine garantierte Rendite zahlt, bei Aktie A nicht.

D. Bei Aktie A wird erwartet, dass sie bei steigenden Zinssätzen ihren Wert besser halten kann als Aktie B.

To respond correctly to the English item, test-takers must know that the financial jargon term "blue chip" refers to stocks from a nationally reputable, high-value corporation with stable performance. The term is known from frequent use in news reports on economy and finance in the U.S. If one does not know the meaning, it is difficult to derive it based on the term alone which, etymologically goes back to poker. To respond correctly to the German item, test-takers must know that the abbreviation DAX (Deutscher Aktienindex) refers to the most important German stock market index, comprising stocks of major companies in Germany. The term is equally known from news reports in Germany, and the meaning is hard to guess. Clues on the meaning are also provided through the opposition of "blue chip" and "new corporation" in the TFL and "new company" and the only slightly more overt description "large DAX company" in the TFL-G; the main task requirement to identify the typical performance of stocks of large, established corporations in comparison to new ones remains unaffected by the adaptation. The term 'blue chip' is becoming more popular also internationally and may not require adaptation in future editions.

32. Which of the following is the best example of a diversified portfolio?

A. Nora purchases several real estate lots in a small town.

B. Nolan owns a U.S. coin collection covering all periods of history.

C. Eva purchases mutual funds with stocks from different industries.*

D. Morgan holds U.S. Treasury bonds with the same dates of maturity.

32. Welches ist das beste Beispiel für ein diversifiziertes Portfolio?

A. Nina kauft mehrere Grundstücke in einer kleinen Stadt.

B. Nico besitzt eine Münzsammlung, die alle historischen Epochen abdeckt.

C. Eva kauft Investmentfonds mit Aktien aus verschiedenen Branchen.*

D. Andrea besitzt deutsche Staatsanleihen mit identischem Fälligkeitsdatum.

To respond correctly to this item, test-takers need to understand the general concept of diversification and portfolio management as well as the related terms and to compare the characteristics of different financial assets. Adaptations in this item included omissions of references to the U.S. context and substitutions with German equivalents: 'U.S. coin collection' was adapted as 'coin collection' and 'U.S. Treasury bonds' with the equivalent 'German government bonds'. Throughout the TFL-G, character names were adapted to maintain the cultural relevance, realism, and foster engagement for test-takers in Germany, including through representation of ethnic diversity. In addition, small modifications in terminology were made: The phrase 'diversified portfolio' was rendered literally as "diversifiziertes Portfolio", resulting in slightly more specialized vocabulary that is used only in specialized financial or academic contexts in German. 'mutual funds' was translated as the more generic 'investment fund'. The test developers judged these linguistically and culturally necessary adaptations and modifications to not significantly alter the meaning or task requirements.

Fig. 1 Sample items from the TFL and TFL-G, adaptations and modifications in bold

for instance, what amount of money the participants have at their disposal per month, whether they own a bank account and/or a credit card, whether their bank account has an overdraft option, whether students still live at home, and who pays for their rent. Finally, participants were asked whether they had informed themselves about a number of financial products. Table 1 gives an overview of young adults' information behavior towards different common financial products in Germany. Since many participants had missing values for these variables, we used multiple imputation with ten data sets. Multiple imputation is applied by deriving missing values within variables from estimations of the predictive distribution (Rubin 1987; Schafer and Olsen 1998). Based on these estimations, a data set is generated in which missing values are 
Table 1 Information behavior towards common financial products

\begin{tabular}{|c|c|c|c|c|c|}
\hline & $\mathbf{N}$ & $\%$ & Valid \% & $\mathrm{N}$ imp & $\%$ imp \\
\hline \multicolumn{6}{|c|}{ Life insurance } \\
\hline No & 832 & 75.1 & 78.3 & 866.7 & 78.2 \\
\hline Yes & 231 & 20.8 & 21.7 & 241.3 & 21.8 \\
\hline Total & 1063 & 95.9 & 100 & & \\
\hline Missing & 45 & 4.1 & & & \\
\hline Total & 1108 & & & 1108 & \\
\hline \multicolumn{6}{|c|}{ Riester retirement plan } \\
\hline No & 926 & 83.6 & 87 & 965.6 & 87.1 \\
\hline Yes & 138 & 12.5 & 13 & 142.4 & 12.9 \\
\hline Total & 1064 & 96 & 100 & & \\
\hline Missing & 44 & 4 & & & \\
\hline Total & 1108 & & & 1108 & \\
\hline \multicolumn{6}{|c|}{ Building loan agreement } \\
\hline No & 752 & 67.9 & 70.9 & 788.6 & 71.2 \\
\hline Yes & 309 & 27.9 & 29.1 & 319.4 & 28.8 \\
\hline Total & 1061 & 95.8 & 100 & & \\
\hline Missing & 47 & 4.2 & & & \\
\hline Total & 1108 & & & 1108 & \\
\hline \multicolumn{6}{|c|}{ Real estate } \\
\hline No & 899 & 81.1 & 84.6 & 936 & 84.5 \\
\hline Yes & 164 & 14.8 & 15.4 & 172 & 15.5 \\
\hline Total & 1063 & 95.9 & 100 & & \\
\hline Missing & 45 & 4.1 & & & \\
\hline Total & 1108 & & & 1108 & \\
\hline \multicolumn{6}{|l|}{ Stocks } \\
\hline No & 833 & 75.2 & 78.3 & 867.9 & 78.3 \\
\hline Yes & 231 & 20.8 & 21.7 & 240.1 & 21.7 \\
\hline Total & 1064 & 96 & 100 & & \\
\hline Missing & 44 & 4 & & & \\
\hline Total & 1108 & & & 1108 & \\
\hline \multicolumn{6}{|c|}{ Equity fund } \\
\hline No & 914 & 82.5 & 85.9 & 953.3 & 86 \\
\hline Yes & 150 & 13.5 & 14.1 & 154.7 & 14 \\
\hline Total & 1064 & 96 & 100 & & \\
\hline Missing & 44 & 4 & & & \\
\hline Total & 1108 & & & 1108 & \\
\hline \multicolumn{6}{|c|}{ Money market account } \\
\hline No & 799 & 72.1 & 75.1 & 833.3 & 75.2 \\
\hline Yes & 265 & 23.9 & 24.9 & 274.4 & 24.8 \\
\hline Total & 1064 & 96 & 100 & & \\
\hline Missing & 44 & 4 & & & \\
\hline Total & 1108 & & & 1108 & \\
\hline \multicolumn{6}{|c|}{ Fixed deposit account } \\
\hline No & 834 & 75.3 & 78.5 & 869.1 & 78.4 \\
\hline Yes & 229 & 20.7 & 21.5 & 238.9 & 21.6 \\
\hline Total & 1063 & 95.9 & 100 & & \\
\hline Missing & 45 & 4.1 & & & \\
\hline Total & 1108 & & & 1108 & \\
\hline
\end{tabular}


Table 2 Financing of rent

\begin{tabular}{llllll}
\hline Financing of rent & $\mathbf{N}$ & $\mathbf{\%}$ & Valid \% & N imp & \% imp \\
\hline No rent to pay & 295 & 26.6 & 28.6 & 312.5 & 28.2 \\
Self-financed & 219 & 19.8 & 21.2 & 247.3 & 22.3 \\
Family-financed & 474 & 42.8 & 45.9 & 496.4 & 44.8 \\
Government grant & 44 & 4 & 4.3 & 51.8 & 4.7 \\
Total & 1032 & 93.1 & 100 & & \\
Missing & 76 & 6.9 & & 1108 & \\
Total & 1108 & & & & \\
\hline
\end{tabular}

imputed by estimated values (see Table 1 "imp" =imputed) ${ }^{9}$. The imputation model included all dependent and independent variables used in the further modeling (see "Empirical modeling and results" section).

The results showed that the majority of young adults had not actively informed themselves about the surveyed financial products. A small share of participants had previously informed themselves about equity funds ( $14.1 \%$ of valid responses) and the Riester retirement plan (13\% of valid responses). The financial product that respondents had the most experience with or information about was a building loan agreement, but that result only applied to less than three in ten students (29.1\% of valid responses).

Table 2 gives an overview of who financed the young adults' rent. Since not all students could be expected to have moved into an own apartment, an option for "no rent to pay" was included.

The results indicated that more than one-fourth of participants (28.6\%) did not need to pay rent; $21.2 \%$ of participants financed their rent themselves; $45.9 \%$ of students reported their family covered their rent; and $4.3 \%$ said they financed it through a government assistance grant.

Participants were also asked whether they owned a bank account and a credit card (Table 3). A follow-up question to the bank account was whether the young adults could also overdraw it or not. Since not all young adults were expected to be familiar with the concept of overdraft or the overdraft conditions of their account, another option "don't know" was added. Only $6.5 \%$ of the surveyed young adults did not have a bank account ${ }^{10}$; however, $21 \%$ of respondents did not know whether they had the possibility to overdraft their bank account. More than half the surveyed participants indicated that they did not

\footnotetext{
9 "N imp" presenting the average number of persons belonging to that category after the imputation. For example, after we had imputed the data, on average, 866.7 of the students did not inform themselves about life insurance, which presents a share of 78.2 percent ("\% imp").

10 The share of test-takers who did not own a bank account was rather small in our sample, with only 69 participants (6.5\%). In Germany, many everyday transactions depend on a bank account (e.g., withdrawing money for cash payments, making wire transfers). Hence, even if it was a small group who did not own a bank account, our findings (see Table 5) indicated that their test results were significantly lower than those of participants with bank accounts. GfK Market Research (2015) estimated that a share of around 9\% of young adults aged 18 to 24 do not have a bank account. However, they did not examine beginning students in particular. In our study, we focused on beginning students in higher education, who on average come from families with higher socio-economic status (see the National Report on Education in Germany by Autorengruppe Bildungsbericht 2016); hence, it was reasonable to expect a slightly lower share of participants without bank accounts for our sample.
} 
Table 3 Ownership of bank account and credit card

\begin{tabular}{|c|c|c|c|c|c|}
\hline & $\mathbf{N}$ & $\%$ & Valid \% & N imp & $\%$ imp \\
\hline \multicolumn{6}{|l|}{ Bank account } \\
\hline No & 69 & 6.2 & 6.5 & 71.2 & 6.4 \\
\hline Yes & 999 & 90.2 & 93.5 & 1036.8 & 93.6 \\
\hline Total & 1068 & 96.4 & 100 & & \\
\hline Missing & 40 & 3.6 & & & \\
\hline Total & 1108 & & & 1108 & \\
\hline \multicolumn{6}{|l|}{ Credit card } \\
\hline No & 595 & 53.7 & 55.9 & 621.1 & 56.1 \\
\hline Yes & 469 & 42.3 & 44.1 & 486.9 & 43.9 \\
\hline Total & 1064 & 96 & 100 & & \\
\hline Missing & 44 & 4 & & & \\
\hline Total & 1108 & & & 1108 & \\
\hline \multicolumn{6}{|c|}{ Account with overdraft option } \\
\hline No & 526 & 47.5 & 51.8 & 572.6 & 51.7 \\
\hline Yes & 277 & 25 & 27.3 & 300.1 & 27.1 \\
\hline Don't know & 213 & 19.2 & 21 & 235.3 & 21.2 \\
\hline Total & 1016 & 91.7 & 100 & & \\
\hline Missing & 92 & 8.3 & & & \\
\hline Total & 1108 & & & 1108 & \\
\hline
\end{tabular}

have an account with an overdraft option. Just under half of the surveyed participants owned a credit card (44.1\%). ${ }^{11}$

The young adults were asked about the amount of money they had at their disposal each month (see Table 4). The results indicated a range of variance between 0 and $3000 €$ a month, with a mean of $551 €$ and the median of $500 €$. To make the distribution less sensitive to outliers, the variable of disposable income was recoded dichotomously. Young adults with a monthly disposable income below $500 €$ were coded as 0 , young adults with a disposable income above $500 €$ were coded as 1 .

\section{Empirical modeling and results}

What follows is the empirical estimation of the models of the relationships between the test score in the dimension 'Banking' and test-takers' financial experiences and information behavior towards specific financial products. The relationship can be modeled from an aggregate or disaggregate perspective based on the characteristic of the dependent variable measuring financial knowledge and understanding. In the first two models, the dependent variable was the aggregate test score in the dimension 'Banking' with experiences with and with information behavior toward financial products. In next two models, the dependent variable was the correct response to a single test item, but two different test items were used for the analysis (30 and 32) that were previously described in "Measurement instrument and sample" section. In contrast to other studies which

\footnotetext{
11 The question on credit card ownership showed that there are obviously large international differences in experience with this financial product. Among young adults aged 17-25 years, a notably higher share of individuals can be expected to own a credit card in the US than in Germany (see Bagnall et al. 2014; German Central Bank 2015; Norden and Weber 2007).
} 
Table 4 Young adults' disposable income

\begin{tabular}{lllllllll}
\hline & $\mathbf{N}$ & & M & Median & SD & Min & Max \\
\cline { 2 - 8 } & Valid & Missing & & & & & & \\
\hline Disposable income per month & 1005 & 103 & 551.72 & 500 & 322.5 & 0 & 3000 \\
\hline
\end{tabular}

solely examine a total score, we also considered results at the single item level in this study, mainly to provide examples illustrating how the overall results are reflected in results on single items.

Table 5 shows the regression results from the first two models on the aggregate score in the dimension 'Banking'. In M1, only experiences with and information behavior towards financial products were regressed on the score. In M2, further relevant covariates (gender, high school GPA, completion of a vocational training, and parents' origin) were included. ${ }^{12}$

In the first model, the mean share of variance explained $\mathrm{R}^{2}$ amounted to $18.0 \%$, which is a considerable share of the total score in the dimension 'Banking. The model shows that information behavior across all financial products (except stocks) is positively correlated to the total score in 'Banking' (see H3). Thus, beginning students who had already actively informed themselves about the surveyed financial products scored better on the test dimension 'Banking' than their fellow students who had not yet gathered respective information. Noteworthy is participants' information behavior towards equity funds. Beginning students who had actively informed themselves about equity funds responded correctly, on average, to two more items compared to their peers who had not informed themselves about equity funds. The results for ownership of a bank account, which was coded as a dummy variable with beginning students without bank account as the reference group, show that students who did not own a bank account scored considerably worse than their peers (see H1a). Moreover, students who did not know at all whether or not their bank account had an overdraft option scored lowest of all, while those students who knew they had an overdraft option on average scored better than their peers who did not know about having an overdraft option by a difference of more than one correct response.

Several other findings are worth noting in Table 5. First, ownership of a credit card had no significant effect in this model, but this outcome was not unexpected (see "State of research and hypotheses" section and see H1b). Not all financial products or practical experience with them may improve financial knowledge and understanding, and that result appears to be the case for credit card ownership. The relationship may depend on other factors that are not fully assessed in this case for young adults in Germany. ${ }^{13}$ Second, income as expected appears to influence financial literacy scores. Students with a monthly disposable income above $500 €$ scored higher than students with a lower disposable income by, on average, 0.6 correct responses (see H2). Finally, students who had

\footnotetext{
${ }^{12}$ Multicollinearity was not an issue in this regression. For all of the analyzed 10 imputed data sets, all the variance inflation factors for all independent variables were below 2 .

13 Ownership of a bank account was also influenced by other characteristics of the young adults, which were not considered further in this paper (see also "Discussion").
} 
Table 5 Multiple linear regressions on the score in 'Banking'

\begin{tabular}{|c|c|c|c|c|}
\hline \multirow[t]{2}{*}{ Variable } & \multicolumn{2}{|l|}{ M1 } & \multicolumn{2}{|l|}{ M2 } \\
\hline & Coefficient B & Standard error & Coefficient B & Standard error \\
\hline Constant & $10.475^{* * *}$ & .345 & $15.335^{* * *}$ & .685 \\
\hline Informed about Riester retirement plan & $.744^{*}$ & .366 & .183 & .352 \\
\hline Informed about building loan agreement & $.777^{* *}$ & .266 & $.513^{*}$ & .249 \\
\hline Informed about stocks & .507 & .329 & -.106 & .317 \\
\hline Informed about equity funds & $2.017^{* * *}$ & .407 & $1.479^{* * *}$ & .383 \\
\hline Informed about money market account & $.665^{*}$ & .297 & .438 & .279 \\
\hline Informed about fixed deposit account & $.843^{* *}$ & .309 & $.594^{*}$ & .290 \\
\hline Owns no bank account & $-2.061^{* * *}$ & .595 & $-1.630^{* *}$ & .559 \\
\hline Bank account with overdraft & $1.170^{* * *}$ & .346 & $1.118^{* * *}$ & .326 \\
\hline Bank account without overdraft & .584 & .316 & .540 & .289 \\
\hline No plausible answer to overdraft question & .759 & 1.060 & .438 & .950 \\
\hline Owns no credit card & .182 & .227 & .077 & .215 \\
\hline $\begin{array}{l}\text { Disposable Income (Upper half of the highest } \\
\text { income) }\end{array}$ & $.631^{*}$ & .271 & .335 & .251 \\
\hline Rent self-financed & -.399 & .383 & -.496 & .360 \\
\hline Rent family-financed & -.499 & .288 & $-.561^{*}$ & .271 \\
\hline Rent government-financed & $-1.996^{* * *}$ & .583 & $-1.488^{* *}$ & .549 \\
\hline Gender (male) & & & $1.544^{* * *}$ & .223 \\
\hline High school GPA & & & $-.918^{* * *}$ & .186 \\
\hline Vocational training (none) & & & $-2.394^{* * *}$ & .358 \\
\hline Parents' origin (not German) & & & $-1.819^{* * *}$ & .232 \\
\hline$R^{2}$ & .180 & & .293 & \\
\hline Corrected $\mathrm{R}^{2}$ & .169 & & .280 & \\
\hline
\end{tabular}

$N=1108 ;{ }^{*} p<0.05 ;{ }^{* *} p<0.01 ; * * * 0<0.001$

their family finance their rent or self-financed their rent through a government assistance grant scored worse relative to students who did not have to pay rent (the reference group).

In M2 (see Table 5), we controlled for further covariates which, according to the current state of research, have shown an influence on knowledge and understanding of personal finance. The covariates included gender (see Atkinson and Messy 2012; Chen and Volpe 2002), migration background (see Brown and Graf 2013; OECD 2017), completion of a vocational training (see Frühauf and Retzmann 2016), and high school GPA (see Erner et al. 2016). As previous studies have shown, male participants, students who have completed a vocational training, students who do not have a migration background and students with better high school GPAs score significantly higher than their peers who have these person characteristics or a worse high school GPA. ${ }^{14}$ Especially the influence of a completed vocational training (Table 5) was very high, which underlines the importance of this type of educational program for knowledge and understanding of personal finance. Controlling for these covariates increased the proportion of explained variance $\mathrm{R}^{2}$ to $29.26 \%$. At the same time, the influence of some of the other variables decreased (cf. coefficient B in M1 and M2 in Table 5). For instance, the influence of knowledge and

${ }^{14}$ In Germany, the high school GPA ranges from 1 = best grade to $4=$ worst possible passing grade. 
understanding of personal finance in 'Banking' on information behavior towards money market accounts was no longer significant. The dichotomous variable of disposable income was not significant either when the above covariates were controlled. Overall, however, the influence of experience and information behavior remained significant. The results indicate that the total score in 'Banking' was positively correlated to experience with and information behavior towards common financial products.

In the next two models, we analyzed whether information behavior towards single financial products and more correct responses to items referring to these products were positively correlated. While the TFL assesses many concepts, we narrowed down the following analyses to the two items on stocks and equity funds (see "Measurement instrument and sample" section). This should provide additional insight into the dimension 'Banking' and could be seen as a way to examine specific contents more closely. Results are not supposed to allow a generalization for the whole dimension 'Banking' but offer a closer look at the contents stocks and equity fund as part of the more general dimension. Table 6 shows the findings of a binary logistic regression for each of the two items.

Both models with covariates indicated that the frequency of correct responses to both items was significantly correlated with information behavior towards equity funds, but not towards stocks. This can also be explained by the fact that information behavior

Table 6 Binary logistic regression on item 30 and item 32 of the TFL-G

\begin{tabular}{|c|c|c|c|c|c|c|}
\hline \multirow[t]{2}{*}{ Variable } & \multicolumn{3}{|l|}{ Item 30} & \multicolumn{3}{|l|}{ Item 32} \\
\hline & Coefficient B & Standard error & $\operatorname{Exp}(B)$ & Coefficient B & Standard error & $\operatorname{Exp}(B)$ \\
\hline $\begin{array}{l}\text { Disposable Income } \\
\text { (upper half of the high- } \\
\text { est income) }\end{array}$ & .102 & -159 & 1.108 & -.011 & .182 & .989 \\
\hline Informed about stocks & .063 & .207 & 1.065 & .385 & .246 & 1.469 \\
\hline $\begin{array}{l}\text { Informed about equity } \\
\text { funds }\end{array}$ & $.545^{*}$ & .253 & 1.725 & $.782^{*}$ & .345 & 2.186 \\
\hline Owns no bank account & -.390 & .386 & .677 & -.252 & .413 & .778 \\
\hline $\begin{array}{l}\text { Bank account with } \\
\text { overdraft }\end{array}$ & .220 & .208 & 1.246 & .412 & .243 & 1.510 \\
\hline $\begin{array}{l}\text { Bank account without } \\
\text { overdraft }\end{array}$ & .014 & .183 & 1.014 & .090 & .204 & 1.095 \\
\hline $\begin{array}{l}\text { No plausible answer } \\
\text { about overdraft }\end{array}$ & .400 & .763 & 1.492 & -415 & .755 & 1.514 \\
\hline Owns no credit card & .023 & .142 & 1.023 & .235 & .162 & 1.265 \\
\hline Rent self-financed & .052 & .214 & 1.053 & .202 & .256 & 1.224 \\
\hline Rent family-financed & -.150 & .177 & .861 & -.132 & .197 & .877 \\
\hline $\begin{array}{l}\text { Rent government- } \\
\text { financed }\end{array}$ & -.016 & .363 & .984 & .170 & .427 & 1.186 \\
\hline Gender (male) & .047 & .147 & 1.048 & .057 & .168 & 1.059 \\
\hline High School GPA & $-.632^{* * *}$ & .128 & .532 & $-.516^{* * *}$ & .143 & .597 \\
\hline Vocational training (none) & $-.628^{* *}$ & .236 & .534 & -.312 & .269 & .732 \\
\hline $\begin{array}{l}\text { Parents' origin (not Ger- } \\
\text { man) }\end{array}$ & $-.422^{* *}$ & .151 & .656 & $-.361^{*}$ & .171 & .697 \\
\hline Constant & $2.523^{* * *}$ & .459 & 12.463 & $2.308^{* * *}$ & .513 & 10.050 \\
\hline Pseudo R² (Cox and Snell) & .064 & & & .054 & & \\
\hline Pseudo R² (Nagelkerke) & .088 & & & .080 & & \\
\hline
\end{tabular}

$N=1108 ;{ }^{*} p<0.05 ;{ }^{* *} p<0.01 ; * * * 0.001$ 
towards stocks and towards equity funds was correlated by a Cramer's V of 0.547 (in the raw data), indicating that, often, the same participants had gathered information on both products. The results also showed systematic effects for the covariates: Students who had completed a vocational training responded correctly to one more item. Students with a better high school GPA and those without migration background responded correctly more often than their peers. When these covariates were controlled, gender had no significant effect on responses to these two items.

\section{Discussion}

Overall, our results indicate that experiences with and active information behavior towards specific financial products shows significant correlations with knowledge and understanding of personal finance in the dimension 'Banking' of the TFL (see H2 and H3). This correlation still holds when other relevant influence factors such as gender, migration background, high school GPA, and completion of a vocational training were controlled. The paper underlines that students who finished a vocational training before entering higher education have a higher knowledge and understanding of personal finance. Future research should examine if this stems from learning opportunities in vocational schools or companies or from more experiences with money management. For example, such students earned their own money for at least 2 years of their vocational training. These relationships can be interpreted as further evidence of the validity of the TFL score in the dimension of banking, since the score is expected to be significantly correlated with these external criteria (see 'nomological validity' and the criterion 'relations to other variables' in AERA et al. 2014). The results support the assumption that the knowledge and understanding assessed by the TFL is related to corresponding knowledge and understanding acquired from experiences with and active information behavior towards financial products.

The analysis of the two individual items (item 30 and item 32) using binary logistic regression further supported the reliability of this interpretation of results in an exemplary fashion: By gathering information on stocks or equity funds young adults acquired knowledge that is particularly relevant for responding correctly to these two items. In detail, beginning students who had already informed themselves about equity funds were better at evaluating risks and costs of stocks and equity funds and had a better understanding of the relationship between a company's success and their stock performance presented in the items. This effect remains significant when prior learning opportunities such as a vocational training and further relevant variables were controlled.

The overall descriptive statistics indicated that only a small share of beginning students had informed themselves about the various financial products (between 12.5 and 27.9\% depending on the product). This relative lack of information is not surprising, given that many beginning students have only just started their own household for the first time in their lives and perhaps become more financially independent from their parents. Still, there is a large share of young adults who could gather more information about financial products. Since hardly any knowledge and understanding of personal finance is taught in general secondary education in Germany (Frühauf and Retzmann 2016), it is up to young adults to gather experiences and inform themselves about products in the area of personal finance. Future research should still examine whether students inform 
themselves more about financial products over the course of their studies, or when they earn their first income, as well as whether a certain percentage of students do not inform themselves about financial products.

\section{Conclusions and limitations}

The positive effect of ownership of a bank account (see H1a) supports the conclusion that young adults who own an account engage more with financial content. Positively, 93.5\% of students in our sample had a bank account. Even though the other group comprised only 69 young adults (6.5\% of all students in the sample), our findings indicate that this group may benefit from targeted trainings for disadvantaged young adults and should not be overlooked. ${ }^{15}$ We also found, however, a significant difference in account ownership depending on migration background. In our sample, 10 percent of students with migration background did not own a bank account compared to 5 percent of the students without a migration background. This finding might point to differences in upbringing with regard to personal finance between families with and without migration background (or specific groups) (see Kim and Chatterjee 2013, p. 64; Mimura et al. 2015). This finding should be further studied in follow-up studies focusing on the disposable income and the information behavior of different groups of young adults, depending on migration background. In our study, we could not differentiate groups of students with different migration backgrounds, but it is probable that there are huge cultural differences depending on their cultural background. It would be interesting to examine whether there are differences in other relevant conditions of socialization, such as pocket money, because there are a few studies showing that young adults who have received pocket money have a higher level of financial knowledge (see OECD 2017, p. 117).

Apart from ownership of a bank account, young adults' depth of understanding of bank accounts can be taken as a differentiating criterion, if we assume that knowing or not knowing the overdraft conditions of one's account represents a suitable indicator of depth of understanding. In the raw data, $21 \%$ of participants did not know whether their account had an overdraft option. These students performed significantly worse than their peers, which indicates that they had informed themselves only unsystematically about the conditions of their bank account-and possibly about other financial products, as well, which would need to be examined. Follow-up studies could examine whether such a lack of knowledge can be explained by a lack of interest and/or a lack of incentive to inform oneself about overdraft conditions or other financial products. So, it might be the case that students who do not intend to overdraft their account see no relevance in informing themselves about overdraft possibilities. Our initial findings show that students who know whether or not they have an overdraft option have higher disposable income compared to their fellow students. This finding can be interpreted as a preliminary indication that students with a lower disposable income are particularly less interested in personal finance. Nevertheless, future studies should ask students how

\footnotetext{
${ }_{15}$ We assume that each of the young adults in our sample will at some point want to earn their own money and need a bank account for it. Hence, all young adults face the necessity to familiarize themselves with bank accounts when entering the job market at the latest.
} 
likely it is that they intend to overdraft their account in the future, because this might be an important indicator.

The hypothesis (H1b) about the relationship between credit card ownership and knowledge and understanding of personal finance is supported by the results from this study. Students who owned a credit card did not score significantly better or worse in their financial knowledge and understanding than students without a credit card. This finding was not completely surprising given that US research has not found a significant effect of credit card use (see Walstad et al. 2010). Ownership of a credit card also was not correlated with financial knowledge in the majority of countries that participated in the financial literacy section of PISA (OECD 2014, p. 102). As outlined in "State of research and hypotheses" section, the spread of credit cards varies within the group of young adults across countries, and in Germany, credit cards are not extensively used by young adults. The findings in this paper indicate that ownership of a credit card alone is not correlated to knowledge and understanding of personal finance in Germany. Follow-up studies should perhaps more closely examine how young adults in Germany use their credit cards, if they have some. It seems, the most important financial product that young adults in Germany should have knowledge about is an own bank account, in which they have to manage their money and can check their deposits. Most banks also provide a debit card along with the account, which shares some of the transaction functionalities of a credit card. So, students in Germany with a bank account can learn to handle electronic payment as soon as they receive their debit card. Therefore, learning to use a credit card might not be an important further step for them. It would be interesting to see if students with a credit card use it differently from students with only a debit card.

The assumption that socioeconomic criteria also determine young adults' disposable income and knowledge and understanding of personal finance is supported by the data on the variable 'Rent financing' in our study. Students who financed their rent through a government grant performed worse on the test, while students who still lived at home or who did not have to pay rent, e.g., because their parents owned the apartment, scored best. Furthermore, the finding that students in the top 50\% disposable income group outperformed their peers also points to effects of socialization (see Breitbach and Walstad 2016, p. 90; Chen and Volpe 1998). Finally, this assumption is also supported by the result that the effect of numerous variables decreased after the covariates gender and migration background were included in the model, suggesting that there could be a relationship between these person-related covariates and experiences and information behavior in personal finance matters, which should be further investigated in follow-up studies. Regarding the analyses related to income, we should note critically that we did not assess the total amount of young adults' fixed monthly expenditures (e.g., for rent). Hence, it was not possible to calculate their income after all responsibilities, based on these data only, but it may be useful for future studies to gather this information.

The analysis of the two single items might be a further indicator that, for example, students with and without migration background might differ in their levels of fundamental knowledge and understanding of personal finance. For instance, students with migration background seemed to be less familiar with the functioning of stocks, as assessed in items 30 and 32, than their fellow students without migration background. This indicates 
there may be differences in the use of certain types of investments. Whether this is a socioeconomic or cultural effect needs to be tested in follow-up studies. As we focused on two items only, we can neither generalize our results to the dimension 'Banking', nor to the whole construct of financial knowledge and understanding. Still, the suggested item-level approach might be useful to investigate the different contents within the dimensions of financial knowledge and understanding more closely and might offer new perspectives compared to analyses of sum scores only.

Irrespective of the exact cause of this effect, we summarize that the findings of this study indicate differences in socialization, the disposable income, and information behavior across different student groups depending on migration background, which in return influence knowledge and understanding of personal finance. Considering that beginning students in higher education are already a very positively preselected sample in terms of educational level, it should be tested whether correlations with socialization and disposable income are even more pronounced among young adults with lower educational qualifications.

Even if the score of the Test of Financial Literacy in the dimension 'Banking' showed correlations with young adults' experience with and information behavior towards personal finance, future studies still need to examine the predictive validity of the test (see AERA et al. 2014). From a generalization point of view, we want to emphasize that we focused on the dimension 'Banking' only and that further research is needed to investigate the relationship of experiences and information behavior with the other two dimensions of knowledge and understanding of personal finance: 'everyday money management' (earning income, buying goods and services) and 'insurance.' Since the test assesses knowledge and understanding, but not behavior, it must be determined whether the assessed knowledge is indeed transferred into effective action in financial decisions. This said, the fact that the experiences and information behavior in our study referring to participants' past actions showed correlations with the test score has led us to expect that the knowledge and understanding assessed by the TFL will likely prove a necessary, if not sufficient condition for competent financial action.

\section{Abbreviations \\ CEE: Council for Economic Education; SD: standard deviation; TFL: Test of Financial Literacy; TFL-G: Test of Financial Literacy-German Version}

\section{Authors' contributions}

All authors contributed substantially to this work. MF, RH and WB developed the theoretical framework of the paper Data analysis for this paper was conducted by MF and RH. All authors discussed the manuscript at all stages. All authors read and approved the final manuscript.

\section{Author details}

1 Faculty of Social Sciences, Economics, and Business Administration, Chair for Business and Economics Education, Otto Friedrich University of Bamberg, Kärntenstraße 7, 96052 Bamberg, Germany. ${ }^{2}$ Department of Law, Business \& Economics, Chair of Business and Economics Education, Johannes Gutenberg University Mainz, Jakob-Welder-Weg 9, 55128 Mainz, Germany. ${ }^{3}$ Department of Economics, 525F College of Business, University of Nebraska-Lincoln, Lincoln, NE 68588-0489, USA.

\section{Acknowledgements}

We are indebted to the two anonymous reviewers who provided very detailed, constructive feedback and helpful guidance in the revision of this paper.

\section{Competing interests}

The authors declare that they have no competing interests. 
Availability of data and materials

Not applicable. There is a copyright on the test instrument by the Council for Economic Education (CEE; US) and the data set cannot be shared.

\section{Consent for publication}

Not applicable.

\section{Ethics approval and consent to participate}

Taking part in the research project was entirely voluntary. All students consented to participate. A ethic committee was established at the end of 2014 at the department of business and economics at the University in Mainz. Until that point the design and the questionnaire was finished. We have still talked to a member of the ethics committee and he remarked no critical points in the questionnaire.

\section{Funding}

This study was funded by Center for Research on Education and Higher Education of the Johannes Gutenberg University of Mainz.

\section{Publisher's Note}

Springer Nature remains neutral with regard to jurisdictional claims in published maps and institutional affiliations.

Received: 8 February 2018 Accepted: 2 January 2019

Published online: 10 January 2019

\section{References}

Allgood S, Walstad WB (2016) The effects of perceived and actual financial literacy on financial behaviors. Econ Inq 54(1):675-697

American Educational Research Association (AERA), American Psychological Association (APA), National Council on Measurement in Education (NCME) (2014) Standards for educational and psychological testing. American Educational Research Association, Washington, D.C

Aprea C, Wuttke E (2016) Financial literacy of adolescents and young adults: setting the course for a competence-oriented assessment instrument. In: Aprea C, Wuttke E, Breuer K, Koh NK, Davies P, Greimel-Fuhrmann B, Lopus JS (eds) International handbook of financial literacy. Springer Science+Business Media, Singapore, pp 397-414. https://doi. org/10.1007/978-981-10-0360-8_27

Atkinson A, Messy F (2012) Measuring financial literacy: results of the OECD/international network on financial education (INFE) pilot study. OECD working papers on finance, insurance and private pensions, 15. OECD Publishing, Paris. https://doi.org/10.1787/5k9csfs90fr4-en

Atkinson A, McKay S, Kempson E, Collard S (2006) Levels of financial capability in the UK: results of a baseline survey. $J$ Consum Res. 47. https://sp.ukdataservice.ac.uk/doc/5697/mrdoc/pdf/5697results.pdf. Accessed 19 Jan 2018

Autorengruppe Bildungsberichterstattung [Authors Group National Educational Reporting] (2016) Bildung in Deutschland (Education in Germany). Autorengruppe Bildungsberichterstattung, Bielefeld

Bagnall J, Bounie D, Huynh KP, Kosse A, Schmidt T, Schuh S, Stix H (2014) Consumer cash usage: a cross-country comparison with payment diary survey data, Bundesbank discussion paper no 13/2014. German Central Bank, Frankfurt on the Main

Barry D (2016) Measurement of young adults' attitudes towards money. In: Aprea C, Wuttke E, Breuer K, Koh NK, Davies P, Greimel-Fuhrmann B, Lopus JS (eds) International handbook of financial literacy. Springer Science+Business Media, Singapore, pp 449-464

Bender N (2012) Selbstreguliertes Geldmanagement Bei jungen Erwachsenen (Self-regulating money management of young adults). Peter Lang, Frankfurt

Bertelsmann Foundation (2004) Finanzieller Analphabetismus in Deutschland (Financial illiteracy in Germany). https:// www.bertelsmann-stiftung.de/fileadmin/files/BSt/Publikationen/GrauePublikationen/GP_Finanzieller_Analphabet ismus_in_Deutschland.pdf. Accessed 18 Apr 2018

Breitbach E, Walstad WB (2016) Financial literacy and financial behavior among young adults in the United States. In: Wuttke E, Seifried J, Schumann S (eds) Economic competence and financial literacy of young adults—status and challenges. Verlag Barbara Budrich, Opladen, pp 81-100

Brown M, Graf R (2013) Financial literacy and retirement planning in Switzerland. Numeracy. https://doi. org/10.5038/1936-4660.6.2.6

Cameron M, Calderwood R, Cox A, Lim S, Yamaoka M (2014) Factors associated with financial literacy among high school students in New Zealand. Int Rev Econ Educ 16:12-21. https://doi.org/10.1016/j.iree.2014.07.006

Chen H, Volpe R (1998) An analysis of personal financial literacy among college students. Financ Serv Rev 7(2):107-128

Chen H, Volpe R (2002) Gender differences in personal financial literacy among college students. Financ Serv Rev 11:289-307. https://doi.org/10.1435/79783

Council for Economic Education (CEE) (2013) National standards for financial literacy. Council for Economic Education, New York. http://www.councilforeconed.org/wp/wp-content/uploads/2013/02/national-standards-for-financialliteracy.pdf. Accessed 19 Jan 2018

Erner C, Goedde-Menke M, Oberste M (2016) Financial literacy of high school students: evidence from Germany. J Econ Educ 47(2):95-105. https://doi.org/10.1080/00220485.2016.1146102

Federal Association of German Banks (BdB) (2015) Jugendstudie 2015 (Youth study 2015). GfK Marktforschung, Nürnberg Förster M, Happ R, Molerov D (2017) Using the US test of financial literacy in Germany-adaptation and validation. J Econ Educ 48(2):123-135. https://doi.org/10.1080/00220485.2017.1285737 
Förster M, Happ R, Maur A (2018) The relationship among gender, interest in financial topics and understanding of personal finance. Empirische Pädagogik 32(3/4):292-308

Frühauf F, Retzmann T (2016) Financial Literacy in Germany. In: Aprea C, Wuttke E, Breuer K, Koh NK, Davies P, GreimelFuhrmann B, Lopus JS (eds) International handbook of financial literacy. Springer Science+Business Media, Singapore, pp 263-276. https://doi.org/10.1007/978-981-10-0360-8_17

German Central Bank (2015) Payment behaviour in Germany in 2014. Third study of the utilisation of cash and cashless payment instruments. German Central Bank, Frankfurt on the Main. https://www.bundesbank.de/Redaktion/ EN/Downloads/Publications/Studies/payment_behaviour_in_germany_in_2014.pdf?_blob=publicationFile. Accessed 19 Jan 2018

GfK Marktforschung [GfK Market Research Consumer Panel Projects] (2015) Jugendstudie 2015. Wirtschaftsverständnis, Finanzkultur, Digitalisierung (Youth study 2015. Business and economics understanding, financial culture, digitalization). GfK Marktforschung i.A. des Bundesverbandes deutscher Banken (Federal Association of German Banks). Nürnberg. https://bankenverband.de/media/files/2015_11_20_BdB_Jugendstudie_2015_Ergebnisbericht_Langf assung-final.pdf. Accessed 29 May 2018

Grohmann A, Menkhoff L (2015) Schule, Eltern und finanzielle Bildung bestimmen das Finanzverhalten (Schools, parents, and financial education determine financial behavior). DIW Wochenbericht (German Institute for Economics Research, weekly report) 28:655-661

Happ R, Förster M (2017) The importance of controlling for socioeconomic factors when determining how vocational training and a secondary school economics class influence the financial knowledge of young adults in Germany. Zeitschrift für ökonomische Bildung 6:121-146

Happ R, Förster M, Rüspeler AK, Rothweiler J (2018) Young adults' knowledge and understanding of personal finance in Germany—interviews with experts and test-takers. Citizsh Soc Econ Educ 17(1):3-19. https://doi.org/10.1177/20471 73417747601

Hastings JS, Madrian BC, Skimmyhorn WL (2013) Financial literacy, financial education, and economic outcomes. Annu Rev Econ 5:347-373. https://doi.org/10.1146/annurev-economics-082312-125807

Huston SJ (2010) Measuring financial literacy. J Consum Aff 44(2):296-316. https://doi.org/10.111 $1 / j .1745-6606.2010 .01170 . x$

Johnson E, Sherraden M (2007) From financial literacy to financial capability among youth. J Sociol Soc Welf 34(3):119-146

Kim J, Chatterjee S (2013) Childhood financial socialization and young adults' financial management. J Financ Couns Plann 24(1):61-79

Liedtke M (2015) The meaning of non formal and informal learning processes of adolescents' financial literacy. In: Paper presented at the IACSEE conference 2015, Georg-August-University, Göttingen, 2-4 July 2015

Lusardi A, Mitchell OS (2011) Financial literacy and retirement planning in the United States. J Pension Econ Financ 10(4):509-525. https://doi.org/10.3386/w17108

Lusardi A, Tufano P (2015) Debt literacy, financial experiences, and overindebtedness. J Pension Econ Financ 14(4):332-368

Lusardi A, Mitchell OS, Curto V (2010) Financial literacy among the young. J Consum Aff 44(2):358-380

Mimura Y, Koonce J, Plunkett SW, Pleskus L (2015) Financial information source, knowledge, and practices of college students from diverse backgrounds. J Financ Couns Plann 26(1):63-78

Norden L, Weber M (2007) Checking account information and credit risk of bank customers. Working papers, University of Mannheim. https://ub-madoc.bib.uni-mannheim.de/1780/1/SSRN_ID1022400_code303097.pdf. Accessed 19 June 2018

OECD (2014) PISA, 2012. Results—students and money. OECD Publishing, Paris. https://doi.org/10.1787/9789264270 282-en

OECD (2017) PISA 2015 (volume IV)—students'financial literacy. OECD Publishing, Paris. https://doi.org/10.1787/97892 64270282-en

Peng T-CM, Bartholomae S, Fox JJ, Cravener G (2007) The impact of personal finance education delivered in high school and college courses. J Fam Econ Iss 28(2):265-284

Remund DL (2010) Financial literacy explicated: the case for a clearer definition in an increasingly complex economy. J Consum Aff 44(2):276-295. https://doi.org/10.1111/j.1745-6606.2010.01169.x

Retzmann T, Seeber G (2016) Financial education in general education schools: a competence model. In: Aprea C, Wuttke E, Breuer K, Koh NK, Davies P, Greimel-Fuhrmann B, Lopus JS (eds) International handbook of financial literacy. Springer Science+Business Media, Singapore, pp 9-23. https://doi.org/10.1007/978-981-10-0360-8_5

Rubin DB (1987) Multiple imputation for nonresponse in surveys. Wiley, New York

Schafer JL, Olsen MK (1998) Multiple imputation for multivariate missing-data problems: a data analyst's perspective. Multivar Behav Res 33(4):545-571

Schuhen M, Schürkmann S (2014) Construct validity of financial literacy. Int Rev Econ Educ 16(Part A):1-11. https://doi. org/10.1016/j.iree.2014.07.004

Schuhen M, Schürkmann S (2016) Construct validity with structural equation modelling. In: Aprea C, Wuttke E, Breuer K, Koh NK, Davies P, Greimel-Fuhrmann B, Lopus JS (eds) International handbook of financial literacy. Springer Science+Business Media, Singapore, pp 383-396. https://doi.org/10.1007/978-981-10-0360-8_5

Sohn S-H, Joo S-H, Grable JE, Lee S, Kim M (2012) Adolescents'financial literacy: the role of financial socialization agents, financial experiences, and money attitudes in shaping financial literacy among South Korean youth. J Adolesc 35(4):969-980. https://doi.org/10.1016/j.adolescence.2012.02.002

Sprenger J (2016) Explanations or advice: the impact of financial literacy on information acquisition behavior. Ruhr Economic Papers 626. https://doi.org/10.4419/86788728

van Rooij M, Lusardi A, Alessie R (2007) Financial literacy and stock market participation. NBER Working Paper 13565. http://www.nber.org/papers/w13565.pdf. Accessed 19 June 2018

Walstad WB, Rebeck K (2016) Test of financial literacy: examiner's manual. Council for Economic Education, New York 
Walstad WB, Rebeck K (2017) The test of financial literacy: development and measurement characteristics. J Econ Educ 48(2):113-122

Walstad WB, Rebeck K, MacDonald RA (2010) The effects of financial education on the financial knowledge of high school students. J Consum Aff 44(2):336-357

Worthington AC (2006) Predicting financial literacy in Australia. Financ Serv Rev 15(1):59-79

Zhan M, Anderson SG, Scott J (2006) Financial knowledge of the low-income population: effects of a financial education program. J Sociol Soc Welf 33(1):53-74

Submit your manuscript to a SpringerOpen ${ }^{\circ}$ journal and benefit from:

Convenient online submission

- Rigorous peer review

- Open access: articles freely available online

- High visibility within the field

Retaining the copyright to your article

Submit your next manuscript at $>$ springeropen.com 